\title{
TWENTY-FOUR POSITION TILT TEST FOR ACCELEROMETER CROSS-AXIAL SENSITIVITY COMPENSATION
}

\author{
Miodrag Z. Malovića , Ljiljana M. Brajovićb, \\ Tomislav B. Šekara ${ }^{\mathrm{C}}$ \\ a University of Belgrade, Faculty of Technology and Metallurgy, \\ Innovation Center, Belgrade, Republic of Serbia, \\ e-mail: ofis@malovic.in.rs, \\ ORCID iD: (i)http://orcid.org/0000-0002-0691-4626 \\ b University of Belgrade, Faculty of Civil Engineering, \\ Department of Mathematics, Physics and Descriptive Geometry, \\ Belgrade, Republic of Serbia, \\ e-mail: brajovic@grf.rs, \\ ORCID iD: Dhttp://orcid.org/0000-0002-2265-7308 \\ ${ }^{c}$ University of Belgrade, School of Electrical Engineering, \\ Signals and Systems Department, Belgrade, Republic of Serbia, \\ e-mail: tomi@etf.rs, \\ ORCID iD: (1)http://orcid.org/0000-0001-8031-3135 \\ http://dx.doi.org/10.5937/vojtehg65-13137
}

FIELD: Electronics

ARTICLE TYPE: Original scientific paper

ARTICLE LANGUAGE: English

\begin{abstract}
:
Cross-axial or transverse sensitivity of an accelerometer can be compensated by digital processing of the output signal. To perform this, it is necessary to determine coefficients that describe a sensor's response to excitation experimentally. Many procedures advised by standards and scientific papers use expensive equipment which is not available in every laboratory. Therefore, a simple method is proposed, namely a variation of the static tilt test, requiring no other measuring equipment than the sensor itself and a flat surface. Results vary depending on sensor surface and housing quality, but it has been shown that cross sensitivity effects can be reduced from several percent usually associated with commercial threeaxial MEMS accelerometers down to $1 \%$ or less.
\end{abstract}

Key words: accelerometers, digital signal processing, acceleration, sensitivity, transverse, sensors, MEMS.

ACKNOWLEDGEMENT: The authors are thankful for the financial support from the Ministry of Education and Science of the Republic of Serbia (national projects TR-36048 and III-44002). 


\section{Introduction}

There are various imperfections influencing accelerometer performances. They are mainly non-linearity (including hysteresis), crossaxial (also referred to as transverse) sensitivity, and dynamic characteristics (primarily bandwidth limitations). Additionally, all of them are subject to temperature fluctuations and aging (Lawrence, 2001). However, some of these effects can be examined experimentally and digital processing can be used to improve the quality of acquired data subsequently.

Transverse sensitivity of three-axial accelerometers is caused mainly by misalignment of their axes, which inevitably occurs in the process of manufacture (Liu, et al, 2009, pp.196-200). Things get worse with miniaturization. While new-generation micro-electro-mechanical (MEMS) accelerometers are more practical than classical ones in many ways, especially in terms of low power consumption (necessary for batterypowered systems), small proof masses and electrodes are more difficult to align properly. Therefore, commercial MEMS accelerometers exhibit higher cross-axial sensitivities, typically equal to several percent (Sysoeva, 2006, pp.28-39).

\section{Theoretical analysis}

A simple method for calibration of accelerometers, for both main axis sensitivity and cross-axial sensitivity, which can be performed in any laboratory, is a so-called tilt test (VTI Technologies, 2005). An accelerometer is placed into six perpendicular positions where $\mathrm{g}$ acts in the directions of $+x,-x,+y,-y,+z$ and $-z$ (shown in Fig. 1), and the output is analyzed. Cross-axial sensitivities are defined as follows:

$T_{x}=\frac{\sqrt{c_{x y}^{2}+c_{x z}^{2}}}{c_{x x}} \quad T_{y}=\frac{\sqrt{c_{y x}^{2}+c_{y z}^{2}}}{c_{y y}} \quad T_{z}=\frac{\sqrt{c_{z x}^{2}+c_{z y}^{2}}}{c_{z z}}$,

where $T_{i}$ is the cross-axial sensitivity for the axis $i(\mathrm{x}, \mathrm{y}$ or $\mathrm{z})$, and $c_{i j}$ are the coefficients from:
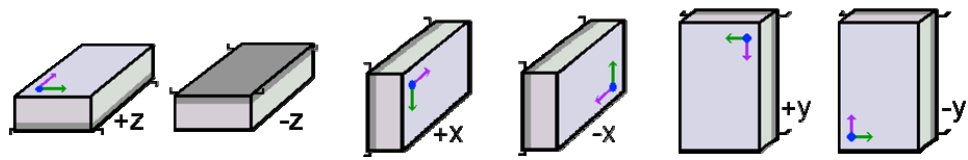

Figure 1 - Tilt test basic positions

Puc. 1 - Основные положения тестирования статичного угла наклона Слика 1 - Основне позиције тилт-теста 


$$
\begin{aligned}
& f_{x}=c_{x x} a_{x}+c_{x y} a_{y}+c_{x z} a_{z}+k_{x} \\
& f_{y}=c_{y x} a_{x}+c_{y y} a_{y}+c_{y z} a_{z}+k_{y} \\
& f_{z}=c_{z x} a_{x}+c_{z y} a_{y}+c_{z z} a_{z}+k_{z},
\end{aligned}
$$

describing the influence of the $j$ axis excitation on the $i$ axis output $f_{j}$. The coefficients labeled $k_{i}$ denote zero offsets (outputs for zero excitation). The cross-axial sensitivity $T_{i}$ is a parameter describing the quality of a sensor (the manufacturer usually specifies its maximum value), but its numerical value alone cannot be used for software correction (signal processing). To do that, it is necessary to determine all $c_{i j}$ and $k_{i}$ coefficients.

The system of three equations with three variables is solved and the inverse equations read:

$$
\begin{aligned}
& a_{x}=\frac{\left(f_{x}-k_{x}\right)\left(c_{y y} c_{z z}-c_{y z} c_{z y}\right)+\left(f_{y}-k_{y}\right)\left(c_{x z} c_{z y}-c_{x y} c_{z z}\right)+\left(f_{z}-k_{z}\right)\left(c_{x y} c_{y z}-c_{x z} c_{y y}\right)}{c_{x x}\left(c_{y y} c_{z z}-c_{y z} c_{z y}\right)+c_{y x}\left(c_{x z} c_{z y}-c_{x y} c_{z z}\right)+c_{z x}\left(c_{x y} c_{y z}-c_{x z} c_{y y}\right)} \\
& a_{y}=\frac{\left(f_{x}-k_{x}\right)\left(c_{y z} c_{z x}-c_{y x} c_{z z}\right)+\left(f_{y}-k_{y}\right)\left(c_{x x} c_{z z}-c_{x z} c_{z x}\right)+\left(f_{z}-k_{z}\right)\left(c_{x z} c_{y x}-c_{x x} c_{y z}\right)}{c_{x y}\left(c_{y z} c_{z x}-c_{y x} c_{z z}\right)+c_{y y}\left(c_{x x} c_{z z}-c_{x z} c_{z x}\right)+c_{z y}\left(c_{x z} c_{y x}-c_{x x} c_{y z}\right)} \\
& a_{z}=\frac{\left(f_{x}-k_{x}\right)\left(c_{y x} c_{z y}-c_{y y} c_{z x}\right)+\left(f_{y}-k_{y}\right)\left(c_{x y} c_{z x}-c_{x x} c_{z y}\right)+\left(f_{z}-k_{z}\right)\left(c_{x x} c_{y y}-c_{x y} c_{y x}\right)}{c_{x z}\left(c_{y x} c_{z y}-c_{y y} c_{z x}\right)+c_{y z}\left(c_{x y} c_{z x}-c_{x x} c_{z y}\right)+c_{z z}\left(c_{x x} c_{y y}-c_{x y} c_{y x}\right)} .
\end{aligned}
$$

\section{Twenty-four position tilt test}

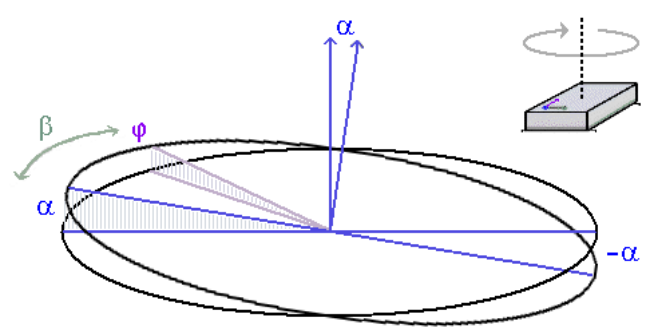

Figure 2 - Rotation of the accelerometer

Puc. 2 - Поворот акселерометра

Слика 2 - Ротација акцелерометра

If there is a small angle $\alpha$ between the actual gravitational field orientation and the three-axial accelerometer main axis, the transverse axes are exposed to gravitational accelerations in the order of $g \cdot \sin (\alpha)$. This function has large variations around zero thus preventing us from 
obtaining reliable coefficients of cross-axial sensitivity by a straightforward tilt test. Let us observe a transverse axis, perpendicular to the main one that is inclined by a small angle $\alpha$ to the vertical (as depicted in Fig. 2). The angle between this axis and the horizontal plane varies in the $-\alpha$ to $+\alpha$ range depending on the angle of rotation around the main axis $\beta$ so that:

$\operatorname{tg} \varphi=\operatorname{tg} \alpha \cos \beta$,

counting $\beta$ from the highest inclination point. It can be approximated by:

$\varphi \approx \alpha \cos \beta$,

provided that $\alpha$ is small. Taking $N$ arbitrary values of $\beta$ which differ by $\Delta \beta=2 \pi / N$ (i.e. uniformly distributed points on the circle), the corresponding average $\sin (\varphi)$ and $\cos (\varphi)$ become zero. The accelerometer rotation thus cancels the main axial sensitivity of each transverse axis to the lateral component $g \cdot \sin (\varphi)$, but not the intrinsic cross-axial sensitivity, the existence of which contributes to the output signal.

A customary method of accelerometer cross-axial sensitivity calibration is placing the sensor into two opposite static positions in each of six basic planes and averaging the output (Sill, Seller, 2006, p.3). This is equivalent to the described rotation with $N=2$ and $\Delta \beta=\pi$. A disadvantage of any static tilt test is the inability to place the sensor into repeatable positions with good relative orthogonality, due to the flexibility of the housing and the plastic board the sensor is attached to, and the unevenness of the surface and the housing (which is prone to non-elastic deformations over time). Another calibration method is to create variations in one axis output of the accelerometer by rotating it in the perpendicular plane, thus exposing it to inertial acceleration in two transverse directions, and then record and process these variations (Dosch, 2000), (Veldman, 2012, pp.254-262). A disadvantage of dynamic methods is the need for complex equipment, not available in every laboratory.

Although the proposed 24-position tilt test $(N=4, \Delta \beta=\pi / 2)$ seems very similar to the 12-position test $(N=2, \Delta \beta=\pi)$, four rotation positions are better not only because there is more data to average. The operator can keep track of the values and repeat the experiment if they do not follow the symmetry rule, which is easily visualized. Four arbitrary angles differing by $90^{\circ}$ should produce output equal to $f_{0}+k \cdot \cos (\beta), f_{0}-k \cdot \sin (\beta), f_{0}-k \cdot \cos (\beta)$, and $f_{0}+k \cdot \sin (\beta)$, where $f_{0}$ is the mean value, and $k$ is a constant depending on $\alpha$ and cross-axial sensitivity. In other words, multiple symmetry must be observed. The mean value from positions 1 and 3 must match the mean value from positions 2 and 4 (to an achievable degree of precision); the difference between positions 1 and 2 must match the difference between positions 3 and 4; etc. Otherwise, the measurement has to be repeated. 
This kind of control cannot be implemented if only two positions per plane are used.

The test has been discussed and performed experimentally with three-axial accelerometers. It could also be conducted with two-axial accelerometers although their smaller cross sensitivity makes it less convenient. Single axis accelerometers have cross sensitivity too low for this method to be feasible in most cases.

\section{Experiments}

The experiments were performed using a wireless sensor device designed primarily for vibrations measurements in civil engineering (Malović et al, 2013, pp.19-26). It is made in surface mount technology and features LIS3LV02DL 3-axial 12-bit digital MEMS accelerometer, with up to $3.5 \%$ cross-axial sensitivity according to manufacturer's specification.

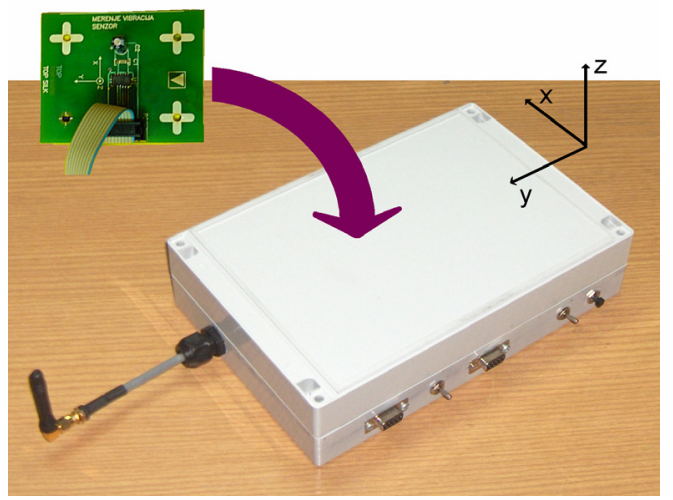

Figure 3 - Sensor device in its plastic housing Puс. 3 - Устройство в пластиковом корпусе Слика 3 - Сензорски уређај у пластичном кућишту

The range and frequency are programmable. Since the excitation in the tilt test ranges within $\pm g$, the shortest range of $\pm 2 g$ was used, as well as the lowest sampling frequency of $40 \mathrm{~Hz}$, for the lowest noise. The accelerometer chip is embedded into a small plastic board and attached to the housing (shown in Fig. 3), separately from the main board. Three pieces were tested by moving the entire housing manually on an ordinary surface such as an office desk. No measuring equipment other than the sensor itself was used.

The devices were programmed to perform series of hundreds of measurements and average the result for each position. Data was acquired by a radio modem (a display could have been attached to serve the same purpose). It is important in an experiment of this type to make 
sure that the accelerometer is allowed minimum freedom of movement in the reference frame of the housing. The accelerometer boards were firmly attached by bolts embedded into the housings.

Table 1 - Experimental results on three different surfaces

Таблица 1 - Экспериментальные результаты по трем различным поверхностям Табела 1 - Резултати експеримената на три различите подлоге

\begin{tabular}{|c|c|c|c|c|c|c|c|c|c|}
\hline & $\mathrm{X} 1$ & $\mathrm{Y1}$ & $\mathbf{Z 1}$ & $\mathrm{X} 2$ & $\mathrm{Y} 2$ & $\mathrm{Z2}$ & $\mathrm{X} 3$ & $\mathrm{Y} 3$ & $\mathrm{Z3}$ \\
\hline \multirow{3}{*}{$\bar{f}(z)$} & -2.12 & 3.16 & +0.59 & 4.68 & -0.12 & -21.69 & -19.57 & -10.34 & +18.02 \\
\hline & +1.05 & $-0.99^{*}$ & 0.18 & +1.92 & -0.30 & -21.86 & -20.61 & -10.15 & +18.82 \\
\hline & 52 & & & 34 & & & & Wr & \\
\hline \multirow{3}{*}{$\Delta f(z)$} & 2.16 & 3.46 & 2069.1 & 9.35 & +4.20 & 2067.7 & -9.69 & $+7.36^{*}$ & 2071.4 \\
\hline & 1.65 & 85 & 2070.1 & 12.64 & +5.72 & 2069.0 & -9.95 & +3.75 & 2071.6 \\
\hline & -31.30 & -15.20 & 2069.4 & +10.20 & +3.37 & 2068.6 & -8.59 & +1.38 & 2071.4 \\
\hline \multirow{3}{*}{$\bar{f}(y)$} & 56 & 36 & +2.79 & 0.16 & +10.45 & -18.54 & -20.31 & -17.40 & +20.85 \\
\hline & 26 & +4.71 & .23 & $+7.01^{*}$ & +9.66 & -20.05 & -19.30 & -17.59 & +24.46 \\
\hline & -8.48 & +4.60 & +3.67 & -4.69 & +10.19 & -18.37 & -26.39 & -17.55 & +20.79 \\
\hline \multirow{3}{*}{$\Delta f(y)$} & +27.76 & 2057.7 & +25.75 & +64.44 & 2043.8 & +5.11 & +38.53 & 2044.9 & +10.23 \\
\hline & + & 2 & + & +69.99 & 3.8 & -3.05 & +3 & 1 & $-7.47^{*}$ \\
\hline & +30. & 2057.2 & +10 & +64.13 & 2044.3 & -5.84 & +49.52 & 2045.0 & +2.63 \\
\hline \multirow{3}{*}{$\bar{f}(x)$} & +4.36 & -2.30 & -5.37 & -2.13 & -5.54 & -26.61 & -18.91 & -16.12 & +12.50 \\
\hline & +4.45 & -2.44 & -6.13 & -1.18 & +0.18 & -24.56 & -19.06 & $-8.70^{*}$ & +15.08 \\
\hline & +4 & & & & -4 & -24.30 & -19.02 & -15.43 & +15.26 \\
\hline \multirow{3}{*}{$\Delta f(x)$} & 21 & & & - & & & $20^{\prime}$ & & \\
\hline & & 0 & +3.8 & 203 & -16 & -50 & 20 & +8.48 & -22.59 \\
\hline & & 2 & & & & & & & 53 \\
\hline
\end{tabular}

The preliminary experiments with the ordinary tilt test in just six positions yielded poor results. Variations of $1 \% \mathrm{~g}$ or more occurred commonly, implying that transverse sensitivity already below $3.5 \%$ cannot be compensated significantly. The results of three 24-position experiments, expressed in raw quanta (the digital output of the chip; 1024 quanta correspond to $g$ nominally) are presented in Table 1 . They were performed on a metal surface, a wooden surface, and a slightly sloped wooden surface $\left(1.5^{\circ}\right)$, to show that a small slope does not influence the results significantly. For clarity reasons, the results from different experiments are displayed in different rows inside the same table cells. The $f(i)$ represents the average output of the channel $i$ from $+g$ and $-g$ excitation in the $j$ direction. This would be zero offset if we suppose that the transfer function is linear. The $\Delta f(i)$ denotes the difference between the two outputs. It should be divided by $2 \mathrm{~g}$ to obtain the coefficients $c_{i j}$ from equations (1)-(3). The column headers show the excitation axis $j$ and the sensor serial number. The sign was omitted for the main axial sensitivities related numbers $(i=j)$ which are always positive and have a nominal value 
of 2048 quanta. The result labeled with an asterisk has the highest deviation from the average for that row. The maximum deviations between the experiments were pointed out this way.

The housing sides are very different, as we can see in Fig. 3 . The $z$ side (in the $x-y$ plane), on which the housing is laid in Fig. 3 , is relatively flat and large. This causes the z-excitation-related coefficients to be most reliable (these coefficients feature in the $x$ and $y$ cross-axial sensitivity). The antenna on the $y$ side can be detached when the housing is laid on that side or the housing can simply hang over the edge of the surface (the device center of mass is still above the contact surface). However, the total surface of this side is smaller, causing the results to be of lower quality (the same unevennesses cause larger orientation changes). Finally, the switches on the front, $x$ side, make the device unable to stand on two supports so it must be hung over the surface edge, only this time the mass center is off, and the operator must hold the device manually. Therefore, the worst results are obtained for the y-direction-related coefficients. The housings were the prototypes used intensively for about two years before these experiments took place, so it is reasonable to suppose that better results could be achieved with newer equipment.

It can be concluded that for the $z$ (most suitable surface of the housing) excitation coefficients, the maximum deviation from the mean value from all experiments is about 3 quanta (one quantum equals approximately $10^{-3} \mathrm{~g}$ ), or $0.3 \%$. For the $y$ excitation coefficients, the maximum deviation from the mean value is about 9 quanta $(0.9 \%)$, and for the worst case, the $x$ excitation coefficients, the maximum deviation is about 13 quanta (1.3\%).

The highest measured cross-axial sensitivity is 3.3\% (for the $x$-axis of sensor 2) so we can conclude that this fits the manufacturer's specification (up to $3.5 \%$ ).

\section{Non-linearity analysis}

According to the manufacturer's specification, the accelerometer has the maximum non-linearity of $3 \%$ full scale. This sheds some doubts on the validity of the model described by equations (2)-(3), without prior examination of the transfer function of the accelerometer main axis. These equations describe a simple linear transfer function. The experiments (Table 1) have shown that the average value of the output $\bar{f}$, which should ideally (assuming no non-linearity) always be equivalent to zero offset $k_{i}$ (regardless of the excitation axis), varies by several per mille $\mathrm{g}$ in most cases (as a function of the excitation axis). For small output changes $(\Delta f)$ in case of excitation in transverse directions, we can state that $\bar{f}(i)$ corresponds to the coefficient $k_{i}$ from equations (2) relatively accurately. 
While a good match between two transverse axes' $\bar{f}$ values indicates that an experiment was conducted well, a match between these and the main axis $f$ implies low non-linearity inside the applied range. Only one of nine cases (Y2 in Table 1) features a deviation higher than $1 \%$, so we can conclude that typical non-linearity in the middle of the range $( \pm \mathrm{g}$ is one half of the programmable range used in the experiments, but one sixth of the maximum range of $\pm 6 \mathrm{~g}$ ) is significantly lower than the one declared for the whole range. To study the non-linearity effects further, experiments with more precise equipment are required.

\section{Conclusion}

The experiments with the 24-position tilt test have shown that it can produce much more repeatable results than the tests with 6 or 12 positions, primarily because of the ability of the operator to control experimental results quality (repeat measurements if necessary). It can be concluded that it is possible to achieve certain degree of precision in crossaxial sensitivity calibration of MEMS accelerometers embedded into plastic housings without any external equipment. Theoretically, it is possible to reduce the maximum cross-axial sensitivity to several parts per thousand. Practical results depend on mechanical parameters (stiffness and evenness of the base surface and the sensor housing, and the quality of accelerometer embedment) as well as the quality of the accelerometer (primarily non-linearity).

Like all electronic components, accelerometers age too, so this type of calibration needs to be performed at least on a yearly basis to maintain its level of accuracy.

\section{References}

Dosch, J.J., 2000. Automated testing of accelerometer transverse sensitivity, PCB Piezotronics Technical note AR-69.

Lawrence, A., 2001. Modern inertial technology: Navigation, guidance and control. 2nd ed. New York | Berlin | Heidelberg: Springer-Verlag.

Liu, Y., Wang, G., Guo, C., 2009. Analysis for transverse sensitivity of the microaccelerometer. Engineering, 1(3), pp.196-200. Available at: http://dx.doi.org/doi:10.4236/eng.2009.13023.

Malović, M., Brajović, L., Mišković, Z., Todorović, G., 2013. Vibration measurements using a wireless sensors network. Technics, 68(special edition), pp.19-26. 
Sill, R.D., Seller, E.J., 2006. Accelerometer transverse sensitivity measurement using planar orbital motion. In: Proc. of 77th Shock and Vibration Symposium, Monterey, CA, USA.

Sysoeva, S., 2006. Avtomobil'nye akselerometry. Chast' 5. Perspektivnaja jelementnaja baza poverhnostnyh kremnievyh emkostnyh MEMSakselerometrov (in Russian). Components and Technology, 4, pp.28-39.

Veldman, C.S., 2012. Implementation of an accelerometer transverse sensitivity measurement system. In: Proc. of Test \& Measurement Conference, Muldersdrift, Gauteng, South Africa, pp.254-262.

VTI Technologies, 2005. Cross-axis compensation, Application note 32. [Internet]. Available at: http://www.mouser.com/pdfdocs/an32_crossaxis_ compensation.PDF. Accessed: 25. January 2017.

КОМПЕНСАЦИЯ ПОПЕРЕЧНОЙ ЧУВСТВИТЕЛЬНОСТИ МЭМС АКСЕЛЕРОМЕТРОВ С ПОМОЩЬЮ ТЕСТИРОВАНИЯ СТАТИЧНОГО УГЛА НАКЛОНА, ПРОВЕДЕННОГО В 24-ЕХ ПОЗИЦИЯХ

Миодраг 3. Малович ${ }^{a}$, Лиляна М. Брайович ${ }^{6}$, Томислав Б. Шекара

а Университет в Белграде, Факультет технологии и металлургии,

Инновационный центр, г. Белград, Республика Сербия

$\sigma$ Университет в Белграде, Строительный факультет, Кафедра математики, физики и начертательной геометрии, г. Белград, Республика Сербия

в Университет в Белграде, Факультет электротехники, Кафедра сигналов и систем, г. Белград, Республика Сербия

ОБЛАСТЬ: электроника

ВИД СТАТЬИ: оригинальная научная статья

ЯЗЫК СТАТЬИ: английский

\section{Резюме:}

Кросс-осевая или поперечная чувствительность акселерометра может быть компенсирована цифровой обработкой выходного сигнала. При этом необходимо экспериментально определить коэфффициенты реакции датчика на сигнал. Для проведения подобных мероприятий, в соответствии с рекомендациями стандартов и научных статей, применяется достаточно дорогое оборудование, которое не все лаборатории могут себе позволить. В данной связи представлен простой альтернативный метод, разновидность тестирования статичного угла наклона, не требующий никаких измерительных приборов, кроме датчика и плоской поверхности.Несмотря на то, что результаты зачастую зависят от качества поверхности и корпуса датчика, на практике было доказано, что значения поперечной чувствительности при 
таком методе значительно снижены (в несколько раз), и что типичная поперечная чувствительность трехосевого МЭМС акселерометра с нескольких процентов достигла значения ниже $1 \%$.

Ключевые слова: акселерометры, цифровая обработка сигналов, ускорение, чувствительность, поперечная, датчики, МЭMC.

КОМПЕНЗАЦИЈА ПОПРЕЧНЕ ОСЕТЉИВОСТИ МЕМС АКЦЕЛЕРОМЕТРА МЕТОДОМ ТИЛТ-ТЕСТА У 24 ПОЗИЦИЈЕ

Миодраг 3. Маловић ${ }^{\text {, }}$ Љиљана М. Брајовић ${ }^{б}$, Томислав Б. Шекара

а Универзитет у Београду, Технолошко-металуршки фракултет,

Иновациони центар, Београд, Република Србија

${ }^{\sigma}$ Универзитет у Београду, Грађевински фракултет, Катедра за математику, физику и нацртну геометрију, Београд, Република Србија

в Универзитет у Београду, Електротехнички факултет, Катедра за сигнале и системе, Београд, Република Србија

ОБЛАСТ: електроника

ВРСТА ЧЛАНКА: оригинални научни чланак

ЈЕЗИК ЧЛАНКА: енгЛескИ

\section{Сажетак:}

Крос-аксијална, односно попречна осетљивост акцелерометра може бити компензована дигиталним процесирањем излазног сигнала. Да би се то извело, потребно је експериментално одредити коефицијенте који описују одговор сензора на побуду. Многе процедуре које се односе на то, а које су препоручене стандардима и научним чланцима, користе скупу опрему која није доступна у свакој лабораторији. Зато је предложен једноставан алтернативни метод, варијација статичког тилттеста, који не захтева никакву другу мерну опрему осим сензора и равне површине. Резултати варирају у зависности од квалитета површине и кућишта сензора, али је показано да се ефректи попречне осетљивости могу смањити бар неколико пута, те да се типична попречна осетљивост комерцијалних троосних МЕМС акцелерометара од неколико процената може лако свести испод $1 \%$.

Кључне речи: акцелерометри, дигитална обрада сигнала, убрзање, осетљивост, попречна, сензори, МЕМС.

Paper received on / Дата получения работы / Датум пријема чланка: 07.02.2017. Manuscript corrections submitted on / Дата получения исправленной версии работы / Датум достављања исправки рукописа: 17.03.2017. 
Paper accepted for publishing on / Дата окончательного согласования работы / Датум коначног прихватања чланка за објављивање: 19.03.2017.

(C) 2017 The Authors. Published by Vojnotehnički glasnik / Military Technical Courier

(www.vtg.mod.gov.rs, втг.мо.упр.срб). This article is an open access article distributed under the terms and conditions of the Creative Commons Attribution license (http://creativecommons.org/licenses/by/3.0/rs/).

(c) 2017 Авторы. Опубликовано в «Военно-технический вестник / Vojnotehnički glasnik / Military Technical Courier» (www.vtg.mod.gov.rs, втг.мо.упр.срб). Данная статья в открытом доступе и распространяется в соответствии с лицензией «Creative Commons» (http://creativecommons.org/licenses/by/3.0/rs/).

(c) 2017 Аутори. Објавио Војнотехнички гласник / Vojnotehnički glasnik / Military Technical Courier (www.vtg.mod.gov.rs, втг.мо.упр.срб). Ово је чланак отвореног приступа и дистрибуира се у складу са Creative Commons licencom (http://creativecommons.org/licenses/by/3.0/rs/).

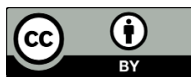

